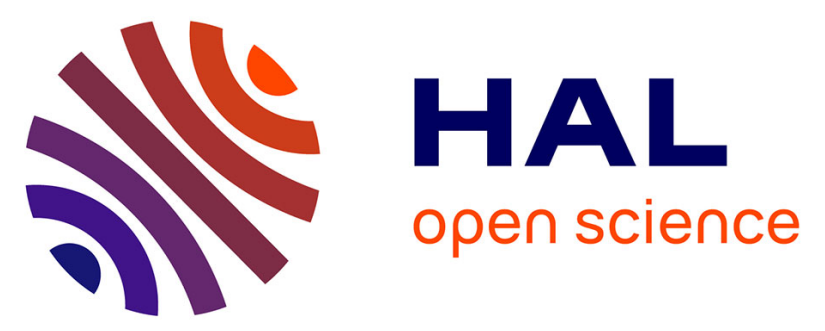

\title{
Multiscale structures of lipids in foods as parameters affecting fatty acid bioavailability and lipid metabolism.
}

Marie-Caroline Michalski, Claude Genot, Constance Gayet, Christelle Lopez, Frédéric Fine, Florent Joffre, Jean-Luc Vendeuvre, Jérôme Bouvier, Jean-Michel Chardigny, Ketsia Raynal-Ljutovac

\section{To cite this version:}

Marie-Caroline Michalski, Claude Genot, Constance Gayet, Christelle Lopez, Frédéric Fine, et al.. Multiscale structures of lipids in foods as parameters affecting fatty acid bioavailability and lipid metabolism.. Progress in Lipid Research, 2013, 52 (4), pp.354-73. 10.1016/j.plipres.2013.04.004 . inserm-00819748

\section{HAL Id: inserm-00819748 https://www.hal.inserm.fr/inserm-00819748}

Submitted on 13 May 2013

HAL is a multi-disciplinary open access archive for the deposit and dissemination of scientific research documents, whether they are published or not. The documents may come from teaching and research institutions in France or abroad, or from public or private research centers.
L'archive ouverte pluridisciplinaire HAL, est destinée au dépôt et à la diffusion de documents scientifiques de niveau recherche, publiés ou non, émanant des établissements d'enseignement et de recherche français ou étrangers, des laboratoires publics ou privés. 
Figure 1. (Summary of the various molecular \& supramolecular structures of lipids in food products...)

\section{(A) Molecular scale}

$$
\begin{aligned}
& \text { - Triacylglycerols } \\
& \text { }
\end{aligned}
$$

- sn-2 monoacylglycerol (2-MAG)

$$
\left.\left.\right|_{\mathrm{OH}}-\mathrm{CH}_{2} \mathrm{C}-\left(\mathrm{CH}_{2}\right)_{n}\right)
$$

- Glycerophospholipids

$$
\text { 筮 }
$$

- sn-2 lysophospholipids

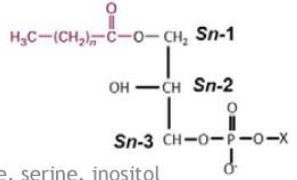

(B) Supramolecular scale

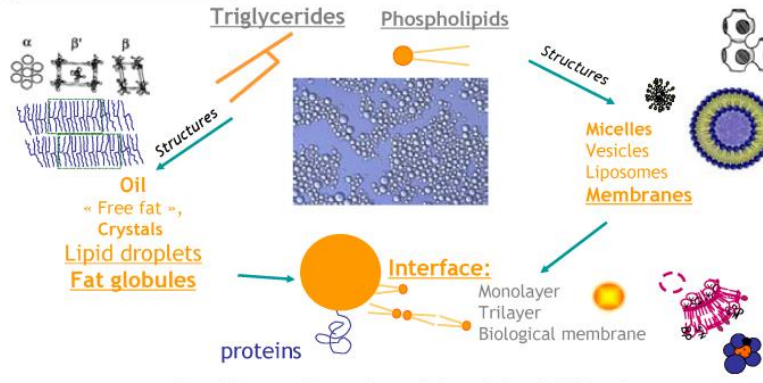

Emulsion $=$ dispersion of droplets stabilized with surface-active molecules

\section{(C) Macroscopic scale}

\footnotetext{
- Continuous lipid phase:

Free fat : oil, lard

Water-in-oil emulsion: butter, margarine

Particles in solid fat: chocolate

- Continuous aqueous phase:

Oil-in-water emulsion : sauce, milk

Intracellular lipid droplets and membane structures
(tissues): meat, egg yolk, vegetables

- Complex solid structure:

Lipid inclusions in a carbohydrate and/or proteinaceous

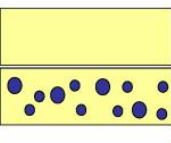


Figure 2. (Importance of supramolecular and triacylglycerol structures on digestion and postprandial lipemia...)

(A) Digestion according to supramolecular structure: emulsified state

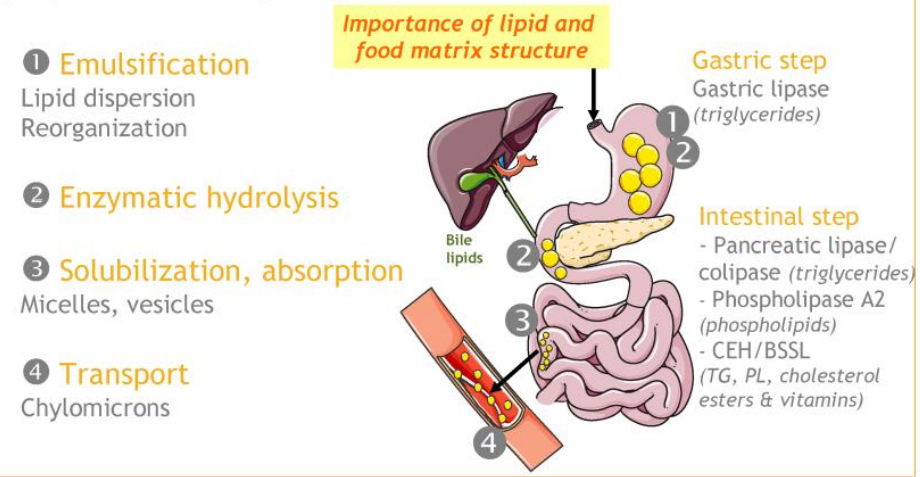

(B) Digestion according to molecular structure: triglycerides

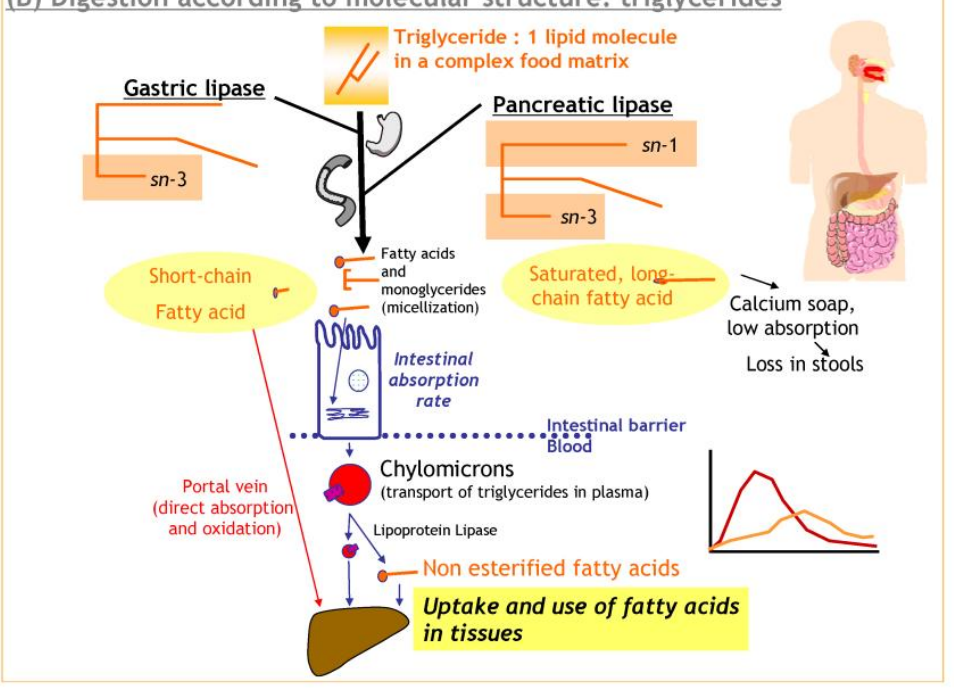


Figure 3. (Thermal behavior of different fats and oils...)

(A)

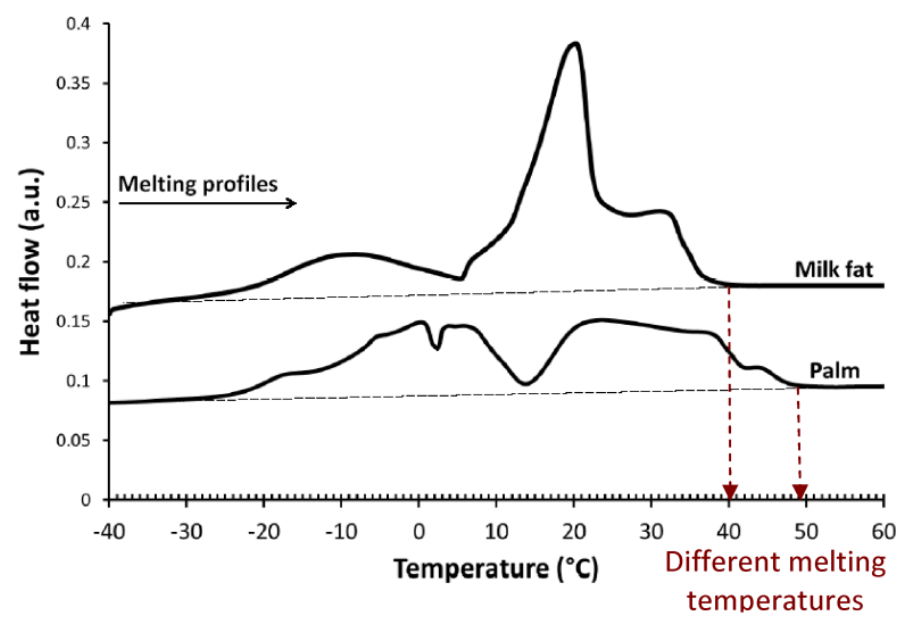

(B)

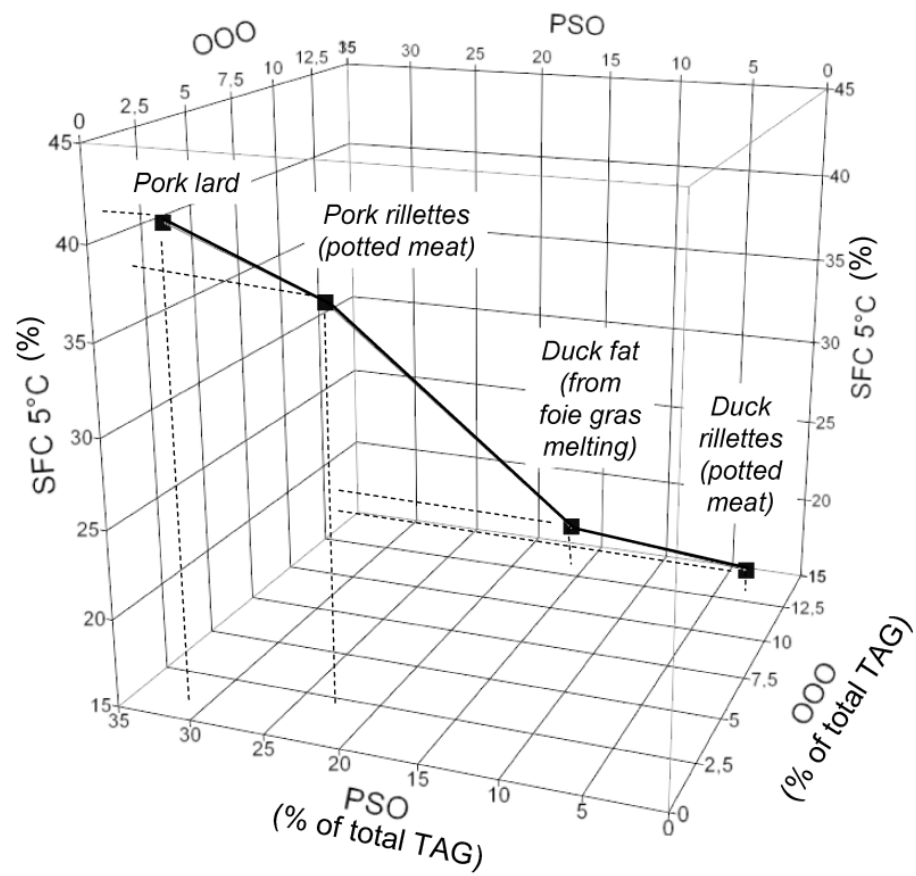

